\title{
LEAF GAS EXCHANGE CHARACTERISTICS OF FOUR PAPAYA GENOTYPES DURING DIFFERENT STAGES OF DEVELOPMENT ${ }^{1}$
}

\author{
ELIEMAR CAMPOSTRINI²; OSVALDO KIYOSHI YAMANISHI ${ }^{3}$ E CARLOS A. MARTINEZ ${ }^{4}$
}

\begin{abstract}
In this research, was used four papaya (Carica papaya L.) genotypes: three from the 'Solo ( Sunrise Solo TJ, Sunrise Solo 72/12 and Baixinho de Santa Amália) group and one from the 'Formosa' group (Know-You 01). They were grown in plastic pots containing a sandy-clay-loam soil subjected to $\mathrm{pH}$ correction and fertilization, under greenhouse conditions. Throughout the experimental period plants were subjected to periodic irrigation to maintain the soil humitidy around field capacity. The experiment was conducted 73 days after sowing. In all genotypes, leaf gas exchange characteristics were determined. The net photosynthetic rate $\left(\mathbf{A}, \mu \mathrm{mol} \mathrm{m}^{-2} \mathrm{~s}^{-}\right.$ $\left.{ }^{1}\right)$, stomatal conductance $\left(\mathbf{g}_{\mathbf{s}}\right.$ mol m$\left.{ }^{-2} \mathrm{~s}^{-1}\right)$, leaf temperature $\left(\mathbf{T}_{\mathbf{r}},{ }^{0} \mathrm{C}\right)$ and intercellular carbon dioxide concentration $\left(\mathbf{c i}, \mu \mathrm{L} \mathrm{L}^{-1}\right)$ on the $4^{\text {th }}$, $5^{\text {th }}, 6^{\text {th }}, 7^{\text {th }}, 8^{\text {th }}$ and $9^{\text {th }}$ leaves from the plant apex were determined. No significant differences were observed for $\mathbf{A}, \mathbf{g}_{\mathrm{s}}, \mathbf{c}_{\mathrm{i}}$, or $\mathbf{T}_{1}$ either among the leaves sampled from any of the genotypes. A was positively correlated with $\mathbf{g}_{\mathbf{s}}$ and in the other hand $\mathbf{T}_{\mathbf{I}}$ and $\mathbf{g}_{\mathbf{s}}$ were negatively correlated. The results suggest that, for 73 DAP, all the sampled papaya leaves functioned as sources of organs.
\end{abstract}

Index terms: photosynthesis, Carica papaya, stomatal conductance, leaf temperature

\section{TROCAS GASOSAS EM FOLHAS DE DIFERENTES ESTÁDIOS DE DESENVOLVIMENTO EM GENÓTIPOS DE MAMOEIRO (Carica papaya L.)}

RESUMO - Neste trabalho, utilizaram-se quatro genótipos de mamoeiro, sendo três genótipos do grupo 'Solo' (Sunrise Solo TJ, Sunrise Solo 72/12 e Baixinho de Santa Amália) e um do grupo 'Formosa' (Know-You 01). As plantas foram cultivadas em potes plásticos, sob condição de casa de vegetação, num solo franco-argilo-arenoso, corrigido, adubado e submetidas a irrigações periódicas até a capacidade de campo. Em todos os genótipos, a taxa fotossintética líquida $\left(\mathbf{A}, \mu \mathrm{mol} \mathrm{m} \mathrm{s}^{-1}\right)$, a condutância estomática $\left(\mathbf{g}_{\mathrm{s}}, \mathrm{mol} \mathrm{m}^{-}\right.$ $\left.{ }^{2} \mathrm{~s}^{-1}\right)$, a temperatura foliar $\left(\mathbf{T}_{1},{ }^{0} \mathrm{C}\right)$, a concentração interna de $\mathrm{CO}_{2}\left(\mathbf{c}_{\mathrm{i}}, \mu \mathrm{L} \mathrm{L}^{-1}\right)$ no mesofilo foliar foram determinadas aos 73 dias após o plantio (DAP), na $4^{\mathrm{a}}, 5^{\mathrm{a}}, 6^{\mathrm{a}}, 7^{\mathrm{a}}, 8^{\mathrm{a}}$ e $9^{\mathrm{a}}$ folhas, contadas a partir do ápice, por meio de um analisador de gás no infravermelho modelo LI6200. Entre as folhas amostradas e entre os genótipos estudados, não foram observadas diferenças significativas nos valores de $\mathbf{A}, \mathbf{g}_{\mathrm{s}}$, $\mathbf{c}_{\mathbf{i}}$ e $\mathbf{T}_{1}$. Foi observado que elevados valores de $\mathbf{g}_{\mathbf{s}}$ proporcionaram valores elevados de $\mathbf{A}$ em todos os genótipos estudados. Contudo, para a característica $\mathbf{T}_{1}$, as relações com $\mathbf{g}_{\mathrm{s}}$ foram inversas, evidenciando a fundamental função do processo transpiratório no resfriamento foliar. Os resultados indicaram que, em todos os genótipos estudados, as folhas avaliadas funcionaram como órgãos fontes.

Termos para indexação: fotossíntese, Carica papaya, condutância estomática, temperatura foliar

\section{INTRODUCTION}

During leaf expansion the net photosynthetic rate (A) reaches a maximum value before maximum leaf area is reached and decreases after leaf maturity. The increase in the net photosynthesis rate is related to several events linked to leaf development: increase in leaf area, leaf thickness, surface and volume of mesophyll cells, leaf inner surface and the dimensions of leaf chloroplasts (Catský \& Sesták, 1997). The pigment contents, stomatal mesophyll conductance increases during leaf development. Also during leaf expansion, the activity of photosynthetic enzymes increases along with the photochemical processes such as light harvest, electron transport chain activity and phosphorylation. The leaf photosynthetic apparatus is completely developed and the maximum $\mathbf{A}$ value is reached when the leaf has 35 to $100 \%$ of its maximum area. The decrease in $\mathbf{A}$, at senescence, is associated to the decrease in both stomatal and mesophyll conductance (Catský \& Sesták, 1997).
Growth of very young leaves depends on photosynthate import from chronologically older leaves (Dickmann \& Kozlowski, 1968; Dougherty et al., 1979; Hanson et al., 1988). During leaf development, the photosynthesis rate decrease perhaps due to carbohydrate accumulation and/or to a limitation in the photosynthetic capability (Suzuki et al., 1987).

According to Tetley \& Thimann (1974) the reduced metabolic activity of chronologically older leaves is due to the amino acid export and is linked to protein degradation. Satler \& Thimann (1977) postulated that stomatal closure could be the primary agent of the beginning of senescence in older leaves. Nevertheless, Okatan et al. (1981) reported that protein and chlorophyll degradation, in soybean, could take place even on absence of yellow leaves.

In relation to papaya that presents a spiral leaf insertion pattern, determining the leaf of greater metabolic activity, related gas exchange, is important for future determinations. This work aimed to determine the gas exchange characteristics, net

1 (Trabalho 048/2001). Recebido: 19/02/2001. Aceito para publicação: 13/09/2001.

2 Eng $^{\circ}$ Agr. Dr. Produção Vegetal, Setor de Fisiologia Vegetal, UENF/CCTA-Av. Alberto Lamego, 2000, 28015620, Campos/RJ

3 Eng. Agr. PhD. Fisiologia de Fruteiras, FAV/UnB, Caixa Postal 04508, Brasília, DF

4 Eng. Agr. Dr. Fisiologia Vegetal, DBV, UFV, 36579000, Viçosa, MG 
photosynthesis rate, stomatal conductance, and intercellular $\mathrm{CO}_{2}$ concentration and leaf temperature, of leaves of four papaya genotypes at different stages of development.

\section{MATERIAL AND METHODS}

Plant Material and Growth Conditions. Four papaya (Carica papaya L.) genotypes: three from the 'Solo ( Sunrise Solo TJ, Sunrise Solo 72/12 and Baixinho de Santa Amália) group and one from the 'Formosa' group (Know-You 01) were grown in $6 \mathrm{~L}$ plastic pots containing a sandy-clay-loam soil subjected to $\mathrm{pH}$ correction and fertilization according to Marin et al. (1993), under greenhouse conditions. During the experimental period the maximum air temperature, the minimum air temperature and the soil temperature were $30.2 \pm 3.1{ }^{\circ} \mathrm{C}, 19.1 \pm 2.1{ }^{\circ} \mathrm{C}$, and $33.5 \pm 2.2$ ${ }^{\circ} \mathrm{C}$, respectively. On the $7^{\text {th }}$ day after planting, two plants were eliminated leaving one plant per pot. At $60 \mathrm{DAP}$, nitrogen fertilization (50 $\mathrm{mg} \mathrm{N} \mathrm{kg}^{-1}$ soil) was applied (Marin et al. 1993). Throughout the experimental period plants were subjected to periodic irrigation to maintain the soil humidity around field capacity.

Physiological Characteristics. The photosynthetic rate $(\mathbf{A})$, stomatal conductance $\left(\mathbf{g}_{\mathbf{s}}\right)$, leaf temperature $\left(\mathbf{T}_{\mathbf{1}}\right)$ and intercellular $\mathrm{CO}_{2}$ concentration (ci), were determined at the 73th DAP using the 4, 5, 6, 7, 8 and $9^{\text {th }}$ leaves, counted down from the plant apex, using a Portable Photosynthesis System, Model LI6200 (LI-COR, USA, Lincoln, NE). Four measurements were performed for each leaf of each genotype, and a $10 \mathrm{~cm}^{2}$ leaf area was used for measurements in a photosynthetic chamber of one liter. The leaves were irradiated by a photosynthetic active radiation (PAR) of $1600 \pm 100 \mu \mathrm{mol} \mathrm{m}^{-2} \mathrm{~s}^{-1}$ emitted by two tungsten-halogen lamps of $500 \mathrm{~W}$. The lamps were set above a transparent glass cuvette containing a $6 \mathrm{~cm}$ layer of continuousflow tap water to filter the heat radiation emitted by the lamps. The leaves were acclimatized under the established radiation level for 20 minutes before measurements. During measurements of the $\mathrm{CO}_{2}$ concentration, the vapor pressure and the air temperature in the photosynthetic chamber were $370 \pm 10 \mu \mathrm{L} \mathrm{L}^{-1}$, $2.0 \pm 0.2 \mathrm{kPa}$ e $28.8 \pm 0.6^{\circ} \mathrm{C}$, respectively.

Data analysis. Results were statistically analyzed as a randomized block design with four replications per treatment. Analysis of variance was determined using the statistical package of Statistica (Statsoft, Inc., Tulsa, OK, USA). Proc ANOVA/ MANOVA was used to obtain means and standard deviations.

\section{RESULTS AND DISCUSSION}

All leaves from the four papaya genotypes showed net photosynthetic rates above $10 \mu$ moles $\mathrm{m}^{-2} \mathrm{~s}^{-1}$ (Fig.1) which suggest that all analyzed leaves possibly behaved as source organs. The gas exchange was not determined on the $1^{\text {st }}, 2^{\text {nd }}$ and $3^{\text {rd }}$ leaves because the size of these leaves since the leaf area was too small to be introduced inside the photosynthetic chamber device and because of the apical position of the leaves which does not leave enough room for measurements.

The $7^{\text {th }}$ leaf of Know-You and Sunrise Solo TJ genotypes presented higher $\mathbf{A}$ than the other leaves (Fig.1). The same response was observed on the $6^{\text {th }}$ leaf of Sunrise Solo $72 / 12$. However, papaya leaves analyzed in the experiment, had active gas exchange and net photosynthesis, including the $8^{\text {th }}$ and $9^{\text {th }}$ leaves, which were chronologically older than the others. The $\mathbf{g}_{\mathrm{s}}$ of all genotypes behaved similarly to $\mathbf{A}$ (Fig.2). Figure 3 shows the relationship between these two characteristics. The good correlation between $\mathbf{A}$ and $\mathbf{g}_{\mathbf{s}}$ indicates a dependence of $\mathbf{A}$ upon the stomatal conductance on leaves of all genotypes analyzed. The stomatal conductance determines the input of $\mathrm{CO}_{2}$ in the leaf affecting the partial pressure of that gas at RUBISCO carboxylation sites (Farquhar \& Sharkey, 1982). Therefore, higher $\mathbf{g}_{\mathrm{s}}$ values may cause higher A values. This statement becomes true if other factors do not limit the process. For the Sunrise Solo $72 / 12$ genotype, the maximum $\mathbf{g}_{\mathrm{s}}$ value was $0.4 \mathrm{~mol} \mathrm{~m}^{-2} \mathrm{~s}^{-1}$, while the other genotypes showed higher values for this characteristic, for example the Sunrise Solo TJ presented values around $0.6 \mathrm{~mol}$ $\mathrm{m}^{-2} \mathrm{~s}^{-1}$.

The intercellular $\mathrm{CO}_{2}$ concentration (ci) was similar among leaves and genotypes (Fig. 4). This characteristic is the result of the balance between the gas assimilation through net photosynthesis rate and its income from the leaf external environment through stomata (Field et al., 1989, Long \& Hallgren, 1993; Mansfield et al., 1990). Possibly, the low variation in ci could be due to the relationship between $\mathbf{A}$ and $\mathbf{g}_{\mathbf{s}}$.

The relationships between $\mathbf{A}$ and $\mathbf{T}_{1}$ and $\mathbf{T}_{1}$ and $\mathbf{g}_{\mathrm{s}}$ are shown in Figures 5 and 6. In general, higher $\mathbf{g}_{\mathrm{s}}$ values were associated to lower $\mathbf{T}_{1}$ values (Fig.6). Probably, the transpiration rate changes caused significative changes in leaf temperature. The transpiration process is the main responsible for the reduction of leaf temperature (Farquhar \& Sharkey, 1982; Nobel, 1991). Although Figure 5 shows little dependence of $\mathbf{A}$ upon $\mathbf{T}_{1}$, the $\mathbf{T}_{1}$ values were affected by $\mathbf{g}_{\mathrm{s}}$ (Fig. 6). Therefore, the variations observed in $\mathbf{A}$ were affected mainly by the variations in $\mathbf{g}_{\mathbf{s}}$ rather than by variations in $\mathbf{T}_{1}$, as no great variations were observed for the air temperature values during the measurements.
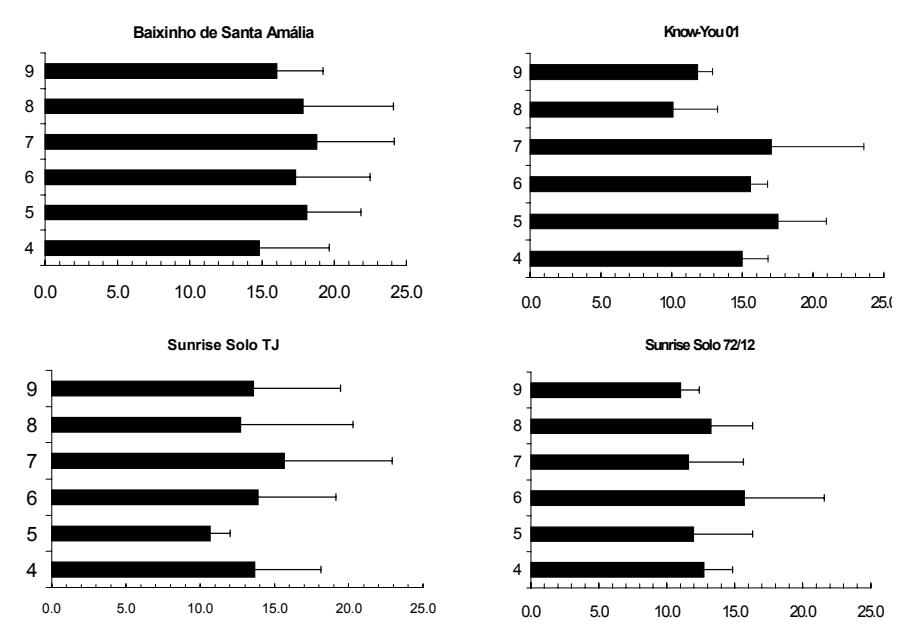

FIGURE 1 - Net photosynthetic rate and leaf number, from the plant apex, of four papaya genotypes. Bars indicate standard deviation and means refers to four determinations. 

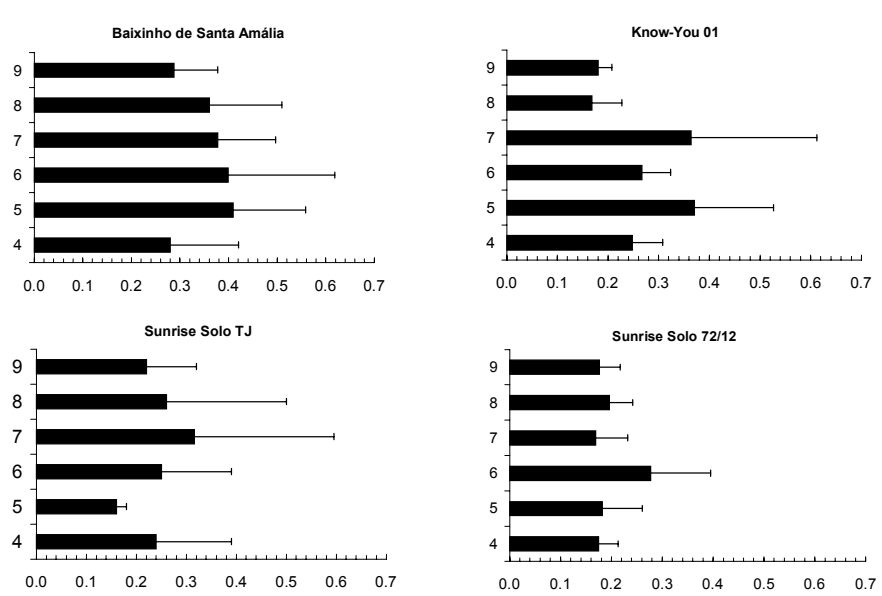

FIGURE 2 - Stomatal conductance and leaf number, from the plant apex, of four papaya genotypes. Bars indicate standard deviation. Means refer to four determinations
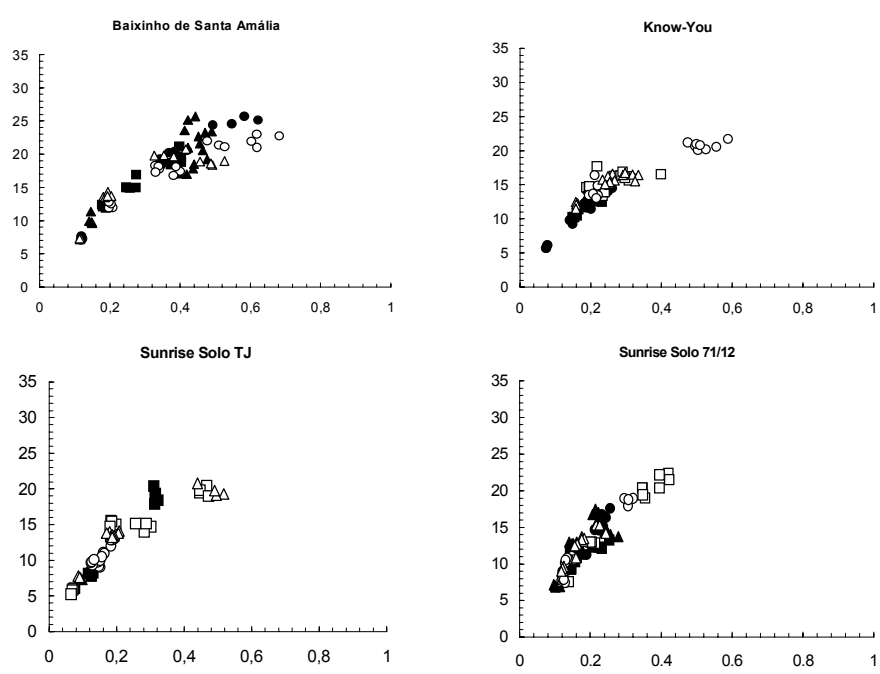

FIGURE 3 - Relationship between net photosynthetic rate and stomatal conductance of four papaya genotypes. $\left({ }_{1}^{\prime}\right.$ leaf 9, ?leaf 8, ? leaf 7, leaf 6, O leaf 5, ? leaf 4, from the plant apex).
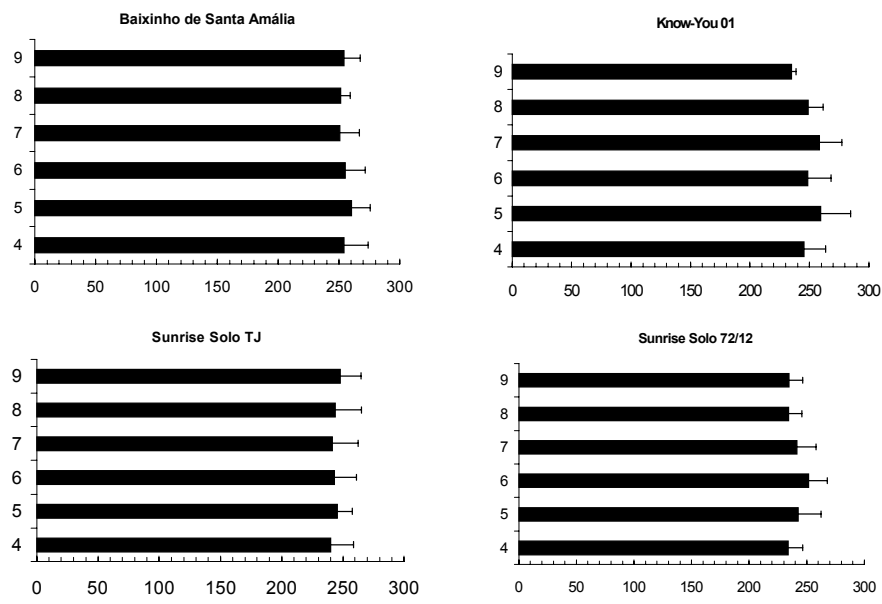

FIGURE 4 - Intercellular $\mathrm{CO}_{2}$ concentration and leaf number, from the plant apex, of four papaya genotypes. Bars indicate standard deviation. Means refer to four determinations
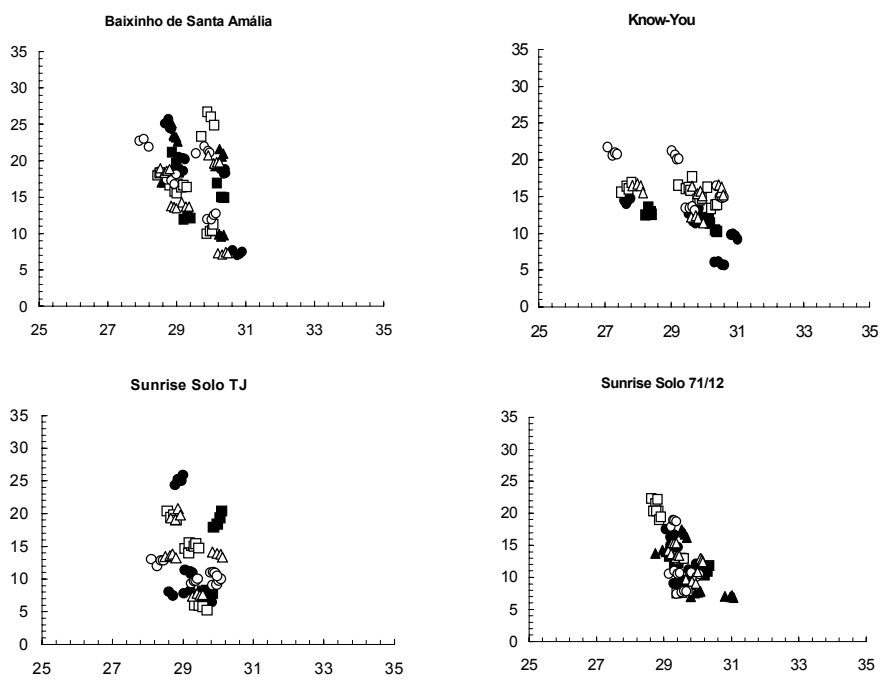

FIGURE 5 - Relationship between net photosynthetic rate and leaf temperature of four papaya genotypes. . ( ${ }_{1}^{1}$ leaf 9, ?leaf 8, ? leaf 7, leaf 6, O leaf 5, ? leaf 4, from the plant apex).
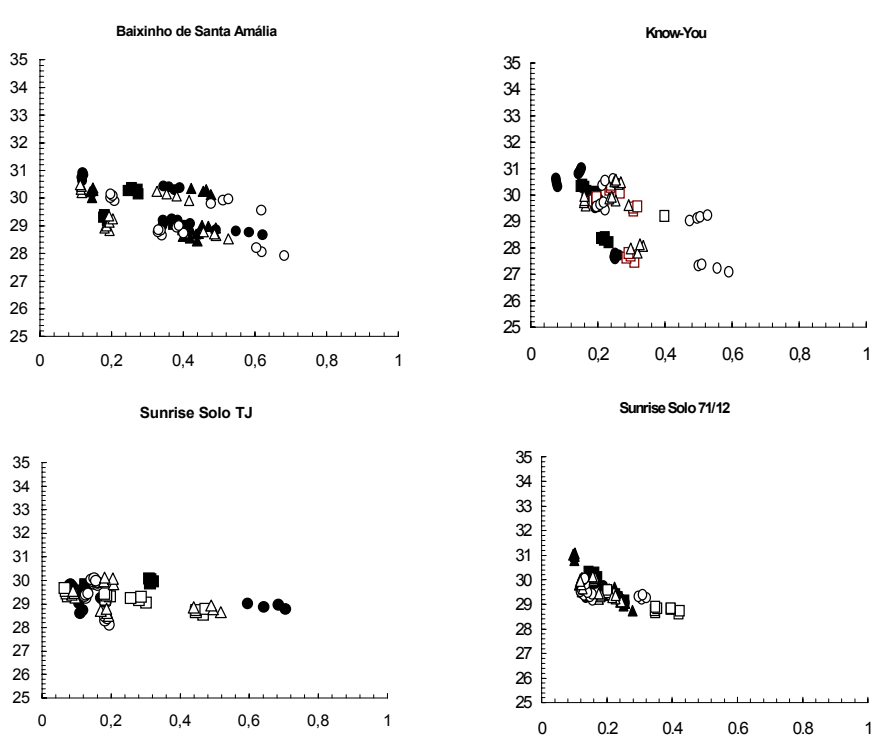

FIGURE 6 - Relationship between leaf temperature and stomatal conductance of four papaya genotypes. . ( (1) leaf 9 , ?leaf 8, ? leaf 7, leaf 6, O leaf 5, ? leaf 4, from the plant apex).

\section{CONCLUSIONS}

All evaluated papaya leaves at the 73th DAP showed higher gas exchange rates. At this time, these leaves were functioning as source organs in all four genotypes. No differences were observed for the gas exchange characteristics between chronologically younger or older leaves. The variations in A value were caused by variations in $\mathbf{g}_{\mathrm{s}}$ rather than in $\mathbf{T}_{\mathbf{l}}$ values. The $\mathbf{T}_{1}$ values were lower for leaves that showed higher $\mathbf{g}_{\mathbf{s}}$ values. Future research should be carried out to determine, for the same genotypes, the drain-source transition stage for the leaves that were not observed $\left(1^{\text {st }}, 2^{\text {nd }}\right.$ and $\left.3^{\text {rd }}\right)$ in this study. 


\section{REFERENCES}

CATSKÝ, J.; SESTÁK, Z. Photosynthesis during leaf development, In: PESSARAKLI, M. (Ed.) Handbook of photosynthesis. New York: Marcel Dekker, 1997. p. 633-660.

DICKMANN, D.I.; KOZLOWSKI, T.T. Mobilization by Pinus resinosa cones and shoots of $\mathrm{C}^{14}$ - photosynthate from needles of different ages. American Journal Botany, Columbios, v.55, p. 900-906, 1968.

DOUGHERTY, P.M.; TESKEY, R.O.; PHELPS, J.E.; HINCKLEY, T.M. Net photosynthesis and early growth trends of a dominant white oak (Quercus alba L.). Plant Physiology, Bethesda, v.64, p. 930-935, 1979 .

FARQUHAR, G.; SHARKEY, T.D. Stomatal conductance and photosynthesis. Annual Review of Plant Physiology and Plant Molecular Biology, Palo Alto, v.33, p.317-345, 1982.

FIELD, C.B.; BALL, T.; BERRY. A.. Photosynthesis: principles and field techniques, In: PEARCY, R.W.; EHLERINGER, J.R.; MOONEY, H.A.; RUNDEL, P.W. (Ed.) Plant physiological ecology. New York: Chapman and Hall, 1989. p. 209-248.

HANSON, P.J., J.G; ISEBRANDS, R.E; DICKSON, R.K; DIXON. Ontogenetic patterns of $\mathrm{CO}_{2}$ exchange of Quercus rubra L. leaves during three flushes of shoot growth.: I. Median flush leaves. Forest Science, Sofia, v.34, p.55-68, 1988.

LONG, S.P.; HALLGREN, J.E. Measurement of $\mathrm{CO}_{2}$ assimilation by plants in the field and the laboratory. In: HALL, D.O.; SCURLOCK, J.M.O.; BOLHÀR-NORDENDAMPF, H.R.; LEEGOOD, R.C.; LONG, S.P. (Ed.) Photosynthesis and production in a changing environment. a field and laboratory manual.
London: Chapman \& Hall, 1993, p.129-165.

MANSFIELD, T.A.; HETHERINGTON, A.M.; ATKINSON, C.J. Some current aspects of stomatal physiology. Annual Review of Plant Physiology and Plant Molecular Biology, Palo Alto, v.41, p.55-75, 1990 .

MARIN, S.L.D.; GOMES, J.A.; SALGADO, J.S.; MARTINS, D.S.; FULLIN, E.A. Recomendações para a cultura do mamoeiro dos grupos 'Solo' e 'Formosa' no Estado do Espírito Santo. Vitória: Emcapa, 1993. (Circular Técnica, 3).

NOBEL, P. Physicochemical and environmental plant physiology. 4. ed. San Diego: Academic Press, 1991. 635p.

OKATAN, N.Y.; KAHANAK, G.M; NOODEN, L.D. Characterization and kinetics of soybean maturation and monocarpic senescence. Physiologia Plantarum, Copenhagen, v.52, p.330-338, 1981 .

SATLER, S.O.; THIMANN, K.V. The relation between senescence and stomatal opening, senescence in darkness. Proceedings of the National Academy of Sciences of the United States of America, Washington, v.70, p.2770-2773, 1977.

SUZUKI, S.; NAKAMOTO, H.; KU, M.S.B.; EDWARDS, G.E. Influence of leaf age on photosynthesis, enzyme activity, and metabolite levels in wheat. Plant Physiology, Bethesda, v.84, p.1244-1248, 1987.

TETLEY, R.M.; THIMANN, K.V. The metabolism of oat leaves during senescence. I. Respiration, carbohydrate metabolism, and the action of cytokinins. Plant Physiology, Bethesda, 54, p.294303, 1974. 